\title{
THE PROBLEM OF TECHNOLOGY OF DESIGNING CREATIVE ACTIVITIES OF STUDENTS IN NATIONAL CRAFTS IN TECHNOLOGICAL EDUCATION
}

\author{
Rita Oteulievna Pakhratdinova \\ Senior Lecturer, Berdakh Karakalpak State University, Uzbekistan
}

\section{ABSTRACT}

The article discusses the use of technology in the design of creative activities of students in the field of national crafts in technology education.

KEYWORDS:- Technology, education, upbringing, student, national craft, interest, creativity, creative activity, creative mastery, creative ability, project, reality, essence, content, strategic, tactical, operational, profession, profession, result.

\section{INTRODUCTION}

In world educational institutions, special attention is paid to creative-modular technologies in the development of technology for designing creative activities of students of national crafts. The International Adult Competency Assessment Program (PIAAC), Student Assessment Assessment (PISA), in assessing the gradual implementation of technology education in connection with the recognition by international organizations as "the main driving force of education and development and an important activity leading to sustainable development goals" (STEM) and the combination of professional skills with personality traits, Systematic work is being carried out to quickly adapt to various changes, to gradually introduce an innovative approach to the educational process, to identify promising areas for modeling the educational process. The
UNESCO Concept of International Education 2030 states that "quality education encourages creative thinking and knowledge, and a high level of literacy and numeracy skills, as well as analytical, problem-solving, thinking and interpersonal skills", special attention is paid. At the international level, special attention is paid to improving the quality of technology education, creative thinking, critical thinking, selfassessment, the design of creative activities of students.

Organization of technology for designing creative activities of students in the field of national crafts in technology education in the world, the development of the personality of schoolchildren, the education of their abilities, moral and aesthetic feelings, interest, desire and desire to read, himself and his surroundings

Incheon Declaration/Education 2030: Towards 
CURRENT RESEARCH JOURNAL OF PEDAGOGICS 2(9): 159-171,

September 2021 DOI: https://doi.org/10.37547/pedagogics-crjp-02-09-34

ISSN 2767-3278

(C)2021 Master Journals

\section{Crossref dof 80 Google}

Accepted 25 $5^{\text {th }}$ September, 2021 \& Published 30th September, 2021

inclusive and equitable quality education and lifelong learning for all (Word Education Forum, 19-22 may 2015, Incheon, Republic of Korea).

research is focused on the development of educational structures aimed at the formation of emotional attitudes to the world around them, pedagogical technologies that help to realize the intellectual abilities of the student. The subject of conceptual scientific research of modern methodology is aimed at creative activity.

Reforms in bringing the education system to a new level of quality in our country have created the necessary conditions for students to acquire knowledge in the basics of science, the formation of spiritual and moral qualities based on basic national and universal values, work skills, creative thinking and a conscious attitude to the environment. There is a need to improve the pedagogical approaches to the organization of technology for the design of creative activities of students in the field of national crafts. Public education system 2030 The concept of development up to the year "Development of teaching methods, the gradual implementation of the principles of individualization in the educational process, the formation of healthy, strong and effective motivation for learning in students"2 important tasks such as Particular attention is paid to the radical reform of general secondary education, the development of creative abilities of students on the basis of international assessment programs. Today, special attention is paid to the quality and effectiveness of technology education in general secondary schools. Special attention is paid to the design of creative activities of students in the field of national crafts, targeted research, taking into account the age characteristics of students. This approach involves designing students 'creative activities in technology education. This can be achieved by designing students' creative activities related to national crafts in technology education and improving strategies for organizing, monitoring and managing the learning process based on teacher-student interaction.

PF-4947 of the President of the Republic of Uzbekistan dated February 7, 2017 "On the Strategy for further development of the Republic of Uzbekistan", PF-5712 of April 29, 2019 "On approval of the Concept of development of public education of the Republic of Uzbekistan until 2030", 21 Decree of the Cabinet of Ministers of the Republic of Uzbekistan No. PF-3850 of October 6, 2017 "On measures to radically increase the prestige and status of the Uzbek language as the state language" This article to some extent contributes to the implementation of the tasks set out in the resolution of April 1, 187 "On approval of state educational standards of general secondary and secondary special, vocational education" and other relevant regulations in this area.

The problem of designing students 'creative activities related to national crafts in technology education is a new, modern direction in the field of didactics, as well as methodological sciences, and the problem of designing students' creative activities is more complex than traditional topics. While the ways and means of conducting scientific research on traditional topics, the principles recognized by the scientific community are defined and polished to some extent, the research methods and tools used in the design of national craft creative activities of students in technology education are not sufficiently studied, principles have not been analyzed. In the problem of designing students' creative activities related to national crafts in technology education - the expression of knowledge, empirical views in such categories as "education", "creative activity", "project", 
CURRENT RESEARCH JOURNAL OF PEDAGOGICS 2(9): 159-171,

September 2021 DOI: https://doi.org/10.37547/pedagogics-crjp-02-09-34

ISSN 2767-3278

(C)2021 Master Journals

\section{Crossref do) 8 Google}

Accepted 25 $5^{\text {th }}$ September, 2021 \& Published 30 ${ }^{\text {th }}$ September, 2021

"design" requires a transition from "essence to reality", "from reality to essence".

The transition from essence to reality is the existing knowledge on the design of creative activities of students in the field of national crafts, from the experience used in the activity to new knowledge, the creativity of students, means moving towards improved experience in designing technology. From reality - to the essence of the technology of designing students' creative activities related to national crafts in the technology education we offer - this is an advanced form of the problem of designing education based on new experimental features, methods used, tools, principles followed.

In our view, creative activity is a learning task developed and performed under the guidance of a teacher that activates students and is aimed at carrying out activities that are new, original and have a certain value in practice. Generalization of ideas about the problem of technology of designing creative activities of students in the field of national crafts in technology education serves as a methodological basis. The problem of designing national creative activities of students in technology education is an organizational system and has a number of unique features: first of all, the design of national creative activities of students in technology education is closely linked with research in didactics and special methods.

In technology education, the technology of designing students' creative activities related to national crafts as an organizational system depends on the will, skill, knowledge of design, experience gained by the researcher. The system of study of educational materials for the design of creative activities of students in the national craft in the teaching of the subject in technology education, educational elements on each topic are allocated, technological maps are developed, students' real knowledge options and skills are explored. On this basis, the features of the design of creative activities of students are identified, and the principles, methods, tools, norms of organization, management, control of student activities in their creation are developed.

In didactic and methodological research, there are a number of advantages, first of all, in the study of the structure of the problem of designing students' creative activity in technology education, as well as the knowledge obtained as a result of the research. Such an analysis clarifies the researcher's perceptions of the problem, providing a comprehensive understanding of the relevance of the topic. When thinking about the technology of designing students' creative activities related to national crafts in technology education It is necessary to distinguish two different meanings:

1. The content of technology education and the system of knowledge, skills, competencies and competencies. It consists of elements such as the technology of designing technology education, the ability of teachers and students to distinguish the purpose of educational tasks, the relevance of educational tasks to the didactic goals of the educational process, the compatibility between the objectives of teaching and learning materials, the development and educational goals of education. one has specific tasks and tools.

2. The process of technology design of creative activities related to national crafts in technology education. Design is one of the important conditions for the organization of the pedagogical process and its successful conduct.

In designing the pedagogical process:

- Analysis of the content of pedagogical activity; -predict the results;

- Tasks such as creating a project for the implementation of planned activities are performed [9]. At this stage, the leading role is played by technological activities designed 
CURRENT RESEARCH JOURNAL OF PEDAGOGICS 2(9): 159-171,

September 2021 DOI: https://doi.org/10.37547/pedagogics-crjp-02-09-34

ISSN 2767-3278

(C)2021 Master Journals

\section{Crossref do) 8 Google}

Accepted 25 $5^{\text {th }}$ September, 2021 \& Published $30^{\text {th }}$ September, 2021

independently by the teacher, as well as in collaboration with the student, based on the definition of the content, means of the learning process. Thus, the design of the pedagogical process is the creation of a project that serves to integrate the overall essence of pedagogical activity, organized on the basis of the trinity "project $\rightarrow$ content $\rightarrow$ activity". Projects differ in subject matter and direction. Analytical activity, which is carried out by the teacher in the projects and ends with the diagnosis; creative activities such as knowing and designing in advance will be demonstrated. Diagnosis, foresight and design are an integral trinity of solving any pedagogical task. The purpose of the project is reflected in advance on paper as a calendar plan, a brief written statement. The effective solution of strategic, tactical and operational tasks depends on the quality of design technology.

The design of the pedagogical process should not only take into account the activities of the teacher, the content and capabilities of the use of pedagogical tools. It should mainly cover the content of the activities organized by the individual student and the group of students.

In the development of the design problem in the theory of pedagogical education, a special place is given to research that is inextricably linked with the concept of "activity" and is considered to be the creation of approximate variants of activity and diagnosis of its results. In this activity, the generation, processing and integration of design ideas and their solutions is a positive result of design.Бизнинг тадқиқотимизда лойихаловчи технология фани ўқитувчиси саналади. Hе can achieve a positive result only through his knowledge, experience, way of thinking, emotional-value attitude to reality. The design expresses the result of solving certain pedagogical technological tasks, which involves the creation, construction and delivery of a specific idea to a useful result in practice [8]. Accordingly, in this study, design is described as a type of professional-pedagogical activity that involves the design, organization, and analysis of the technological process of education.

Аёнки, лойихалаш фаолияти тузилмасида фаолиятнинг икки даражаси observed: the creative nature of design, which involves the creation of new knowledge in the form of a project; the individual nature of the design, which reflects the personality of the teacher in the project, created on the basis of the study of the experience of advanced educators. Design activities should be considered as part of the professional competence of the teacher, which represents the unity of theoretical and practical training for the implementation of pedagogical activities and characterizes the professional quality. Theoretical preparation for design activities is a high level of mastery of a set of design skills and competencies.

Design is a general strategy that reflects the pedagogical process of education, based on social, pedagogical goals. Curriculum, programs, textbooks, methodical recommendations and other training manuals serve as an important source in the design. A full understanding of the pedagogical situation and a clear and correct definition of tasks is an important condition for the effective solution of the pedagogical process.

The pedagogical goal is accepted as a pedagogical task at the stage of preparation for the organization of the pedagogical process. The success of pedagogical activity depends on the understanding of the essence of different tasks one way or another. It is important to identify tasks that are common to pedagogical activity. Then it is expedient to clearly define step-by-step tasks (separate stage tasks) that clearly express the essence of a certain stage of the pedagogical process, and finally special (situational) pedagogical tasks (Figure 1): 


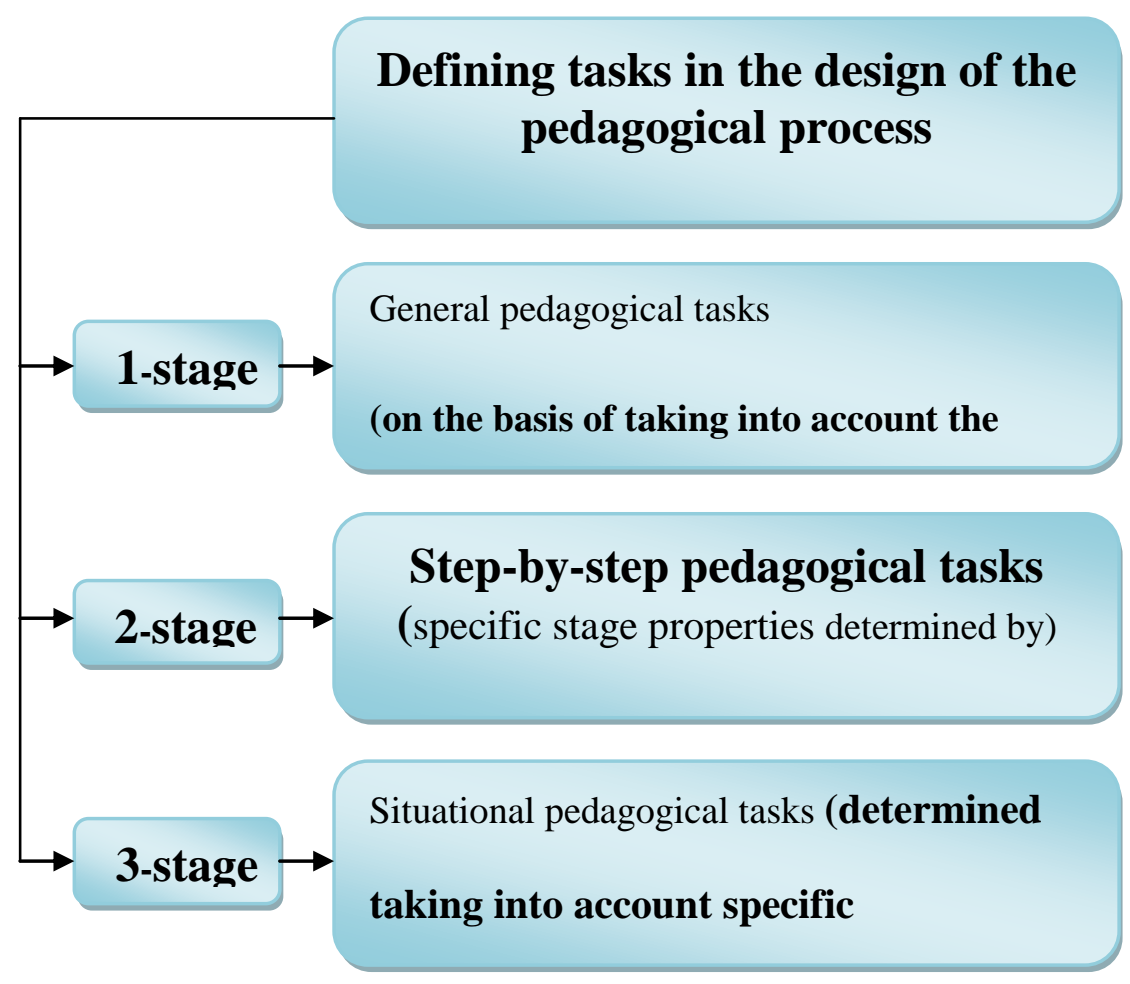

Figure 1. The pedagogical goal is a pedagogical task at the stage of preparation for the organization of the pedagogical process

If the pedagogical situation is not understood sufficiently correctly, then the ways of solving pedagogical tasks are also not defined correctly. Due to the inexperience of a teacher who has just started his / her professional activity, he / she does not have the ability to correctly understand the pedagogical situation and set tasks correctly. Therefore, they act on their own and try to solve the pedagogical task immediately, resulting in a serious mistake. But in some cases, even experienced educators neglect to properly understand the pedagogical situation. As a result, there is a disproportion in pedagogical activity: the educator activates students, uses visual aids, and controls knowledge without thinking about whether their activities can ensure the achievement of pedagogical goals. Another asymmetry of pedagogical activity is that most educators replace pedagogical tasks with secondary, functional, transient tasks and focus only on them.

Understanding the pedagogical task serves as the basis for analysis and diagnostics of data. Therefore, the definition of the situation of the 
CURRENT RESEARCH JOURNAL OF PEDAGOGICS 2(9): 159-171,

September 2021 DOI: https://doi.org/10.37547/pedagogics-crjp-02-09-34

ISSN 2767-3278

(C)2021 Master Journals

Crossref do: 81 Google

Accepted 25th September, 2021 \& Published 30th September, 2021

situation, the analysis of this data should be directed to the identification of key components of the entire pedagogical process, as a teacher, a student and the interaction between them, as well as the content of teaching, effective tools of pedagogy.

Analysis of this - this is a systematic study of the nature of the pedagogical process, the state of the collective and individual behavior in specific situations, pomogaet imet nauchnыe dokazatelstva, takie kak. These testimonies constitute the basis of practical action. The available evidence allows to diagnose the course of the pedagogical activity and the guarantee of the expected result. In our opinion, it is appropriate to highlight the essence of the concept of "diagnosis" here. Diagnosis (Greek diagnostikos - quick comprehension) was originally a concept used in medicine, and was recognized as a doctor's conclusion, which means a comprehensive study of the nature of the disease and the patient's condition. In recent years, the concept of "diagnosis" is widely used in practical pedagogy. Pedagogical diagnosis is an assessment of the pedagogical process through its general condition, as well as a comprehensive, holistic examination of its components.

Pedagogical diagnosis is usually made on the basis of taking into account the psychological, subjective features of the pedagogical process (psychodiagnostic examination). Psychodiagnostic examination is based on a holistic or specific coverage of the student's personality and his activities. The psychodiagnostic examination may be rapid or continuous depending on the duration (Figure 2):

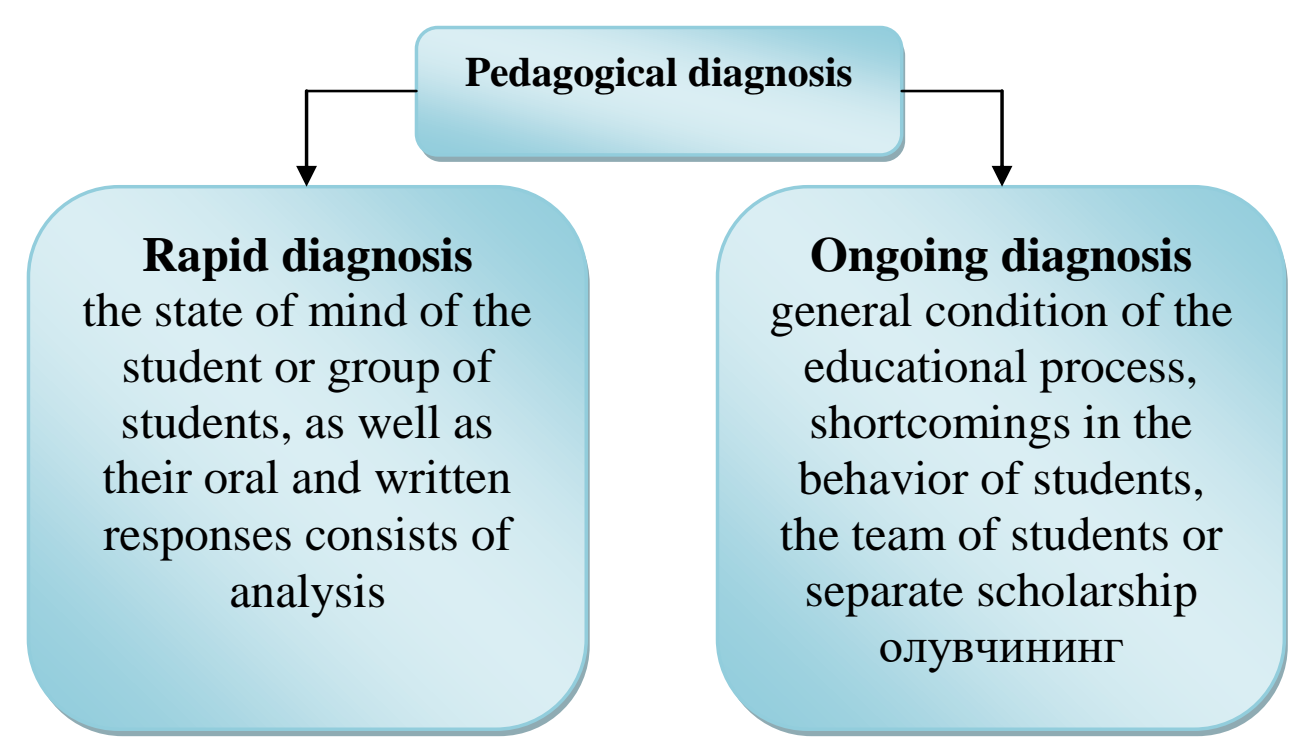

Figure 2. Duration of psychodiagnostic examination 
CURRENT RESEARCH JOURNAL OF PEDAGOGICS 2(9): 159-171,

September 2021 DOI: https://doi.org/10.37547/pedagogics-crjp-02-09-34

ISSN 2767-3278

(C)2021 Master Journals

Crossref do: 81 Google

Accepted 25 $5^{\text {th }}$ September, 2021 \& Published 30th September, 2021

The need for a qualified pedagogical diagnosis requires the teacher to study in depth the methods and special techniques of studying the student's personality, the team, as well as the characteristics of the whole pedagogical process. Diagnosis is a general requirement for addressing the goals and objectives of education (or upbringing). It is closely related to the accuracy, uniformity of goals, methods of achieving them, measurement and evaluation.

The basis of pedagogical diagnosis is a comprehensive knowledge of the student's personality, the study of the characteristics of the class as a team, the analysis of data in specific pedagogical situations, they provide an opportunity to move on to the next important stage of designing the educational process, i.e. to anticipate the pedagogical process. This situation leads to the formation of a pedagogical goal and allows to define well-thought-out pedagogical tasks on the basis of the goal. Prevention of failure to achieve a pedagogical goal is achieved only when the level of development of the individual is consistent with the goals of education. That is, the pedagogical goal set by the teacher is considered as an important factor of this system.

Based on the object of research and the given analysis, we identify the following problems for a systematic study of the problem of technology for designing creative activities of students in national crafts in technology education:

- To study the technology of designing creative activities of students in the field of national crafts as a methodological problem in technology education;

- Analysis of the technology of designing creative activities of students in the field of national crafts as a process in technology education;

- Modeling the activities of educational entities in the technology of designing creative activities of students in the field of national crafts in technology education;

- development of methods for the use of technology tools for the design of creative activities of national crafts on the subject of technology;

- To study the effectiveness of project education in the field of national crafts on the subject of technology;

- after noting the problems in the technology of designing creative activities of students in the field of technology in national education, there is a need to analyze each of them separately, to identify their components.

Understanding the necessity of a problem posed in this or that field of science is a subjective phenomenon: if it interests one, another may be indifferent to it. Understanding the relationship between learned and unstudied issues is a unique temporal intersection. "Temporal intersection is a part of the material world that interests the researcher" [9]. The purpose of the temporary intersection, depending on the result obtained. Consequently, the study of the content of a problem provides a conscious perception of its essence, the relationship between learned and unstudied problems.

By analyzing the problem of creative organization of technological education in terms of the process of knowing the problem, we distinguish three different processes that are interrelated: the researcher's analysis of the separated problem (1); the researcher's study of the teacher's performance on the selected problem (2); the researcher's chosen problem is to visualize student activities in the context of creative learning (3). All three of these issues are related to the process of learning didactic phenomena, and their It is impossible to understand the problem of creative organization of primary education without analyzing its 
CURRENT RESEARCH JOURNAL OF PEDAGOGICS 2(9): 159-171,

September 2021 DOI: https://doi.org/10.37547/pedagogics-crjp-02-09-34

ISSN 2767-3278

(C)2021 Master Journals

Crossref do: 81 Google

Accepted 25th September, 2021 \& Published 30 ${ }^{\text {th }}$ September, 2021

features [9].

The creative organization of technological education is a separate perspective of education that operates in a "researcher-problem" system. Thinking of the problem as a whole system, its components are separated. Separated components - communication by components, relationships are defined. These pave the way for the separation of hierarchical components - from top to bottom, from general to specific. According to the systematic analysis, the interrelated parts of the creative organization of technology education are distinguished: the organization of creative education; creative assimilation of information content; fostering creative abilities in students. In order to clarify our understanding of the problem of organizing students' creative activities related to national crafts in technology education, Figure 3 is presented [9].

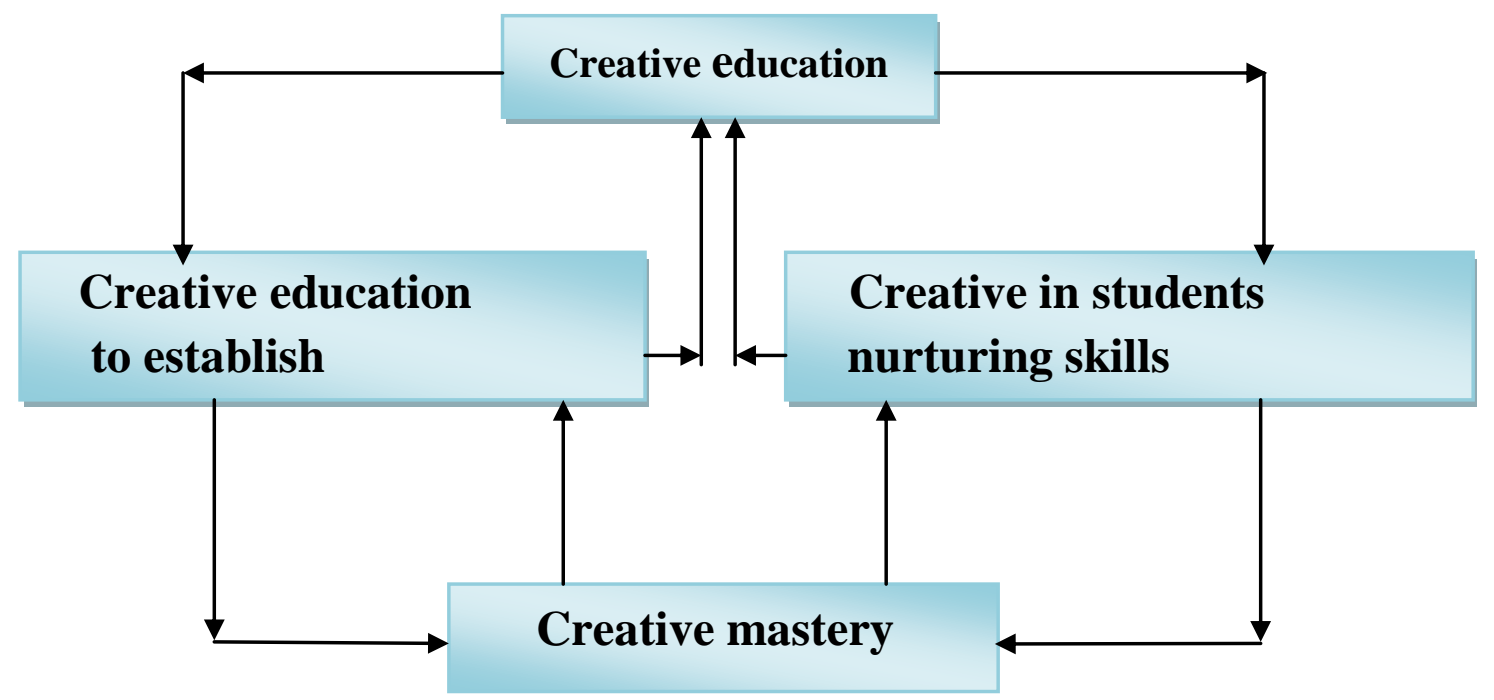

Figure 3. Creative organization of technological education

the structure of the problem.

The outer lines in the picture reflect the process of learning creative learning. Indeed, by distinguishing creative education from noncreative education, the creative organization of education is focused on the analysis of students 'creative mastery and the development of their creative abilities. The inner lines reflect the process of realization of creative learning. Creative mastery through the education of creativity in students, the creative organization of education.

The separated components are interconnected in the form of cause and effect: the creative organization of education is the activity of the teacher. Only when education is creatively organized do students master learning materials creatively. Creative mastery is a student activity. Creative mastery in turn fosters creativity in students. Because the listed components are hierarchically arranged, the next component is considered an open system relative to the previous one. Creative education is a special approach to equipping young people with social experience is an education designed for students 
CURRENT RESEARCH JOURNAL OF PEDAGOGICS 2(9): 159-171,

September 2021 DOI: https://doi.org/10.37547/pedagogics-crjp-02-09-34

ISSN 2767-3278

(C)2021 Master Journals

\section{Crossref do) 8 Google}

Accepted 25 $5^{\text {th }}$ September, 2021 \& Published $30^{\text {th }}$ September, 2021

'thinking. It operates within the framework of the organizational system above it - the work of society in the field of youth education, covers the problems of subordinate organizational systems - the creative assimilation of information content, the development of creative abilities in students.

From the point of view of society, creative education is a forward-looking activity that meets the requirements of the times, the needs of educating a harmoniously developed person, its establishment and dissemination among teachers leads to the formation of new pedagogical practices, new educational systems, principles, tools, organizational forms.

Another component of the organization of technology for designing creative activities of students in the field of national crafts in technology education is the creative mastery of the content of information and part of it educational materials [9]. Creative learning can be compared to non-creative learning - verbal learning. At the heart of verbal education lies the memory of children. It is an education for memory. Creative education is an activity designed for thinking, and therefore for children to think independently and learn creatively. Assimilation is a broad concept that means adding one's own experience to the experience of others.

Creative mastery is an integral part of the organizational system above it, and the component behind it is the condition for the development of creative abilities. After all, without fully understanding the essence of creative mastery, it is impossible to understand the problem of developing creative abilities.

In understanding the essence of creative mastery, in its analysis we use a number of concepts - the apparatus of logical analysis. Such concepts include the categories of purpose and task, means, and outcome.
The category of "goal" refers to the concepts of "highest dream (ideal)", "future perspective". A person can achieve the highest dream only if he strives for the goals he has set for himself, when he works tirelessly on himself. Achieving a goal is a dream come true, an approach to the future. "The goal is the image of the preconceived result, to which all human action is directed" [9].

In the psychological literature, human behavior is analyzed as a goal-oriented system [8]. Due to the participation of two subjects in education teaching and learning activities, two different goals are distinguished: the purpose of teaching; purpose of reading. In education, there are two types of events - conflict and competition, due to the existence of teaching and learning objectives, and cooperation (cooperation). In science, if the activities of each member of the team are not dependent on the activities of the others, the competition will lead to higher results, it has already been proven that when activities come from a single point, they lead to higher results through collaboration. The interaction of teaching (teacher activity) and reading (student activity) requires not the compatibility of goals, but rather their interdependence. In traditional educational theory and related pedagogical practice, the organization of education based on the goals of the teacher leads to such phenomena as some conflict, misunderstanding, resistance, non-recognition of cooperation between the subjects of education - teacher and student. With this in mind, we try to substantiate the problem of creative organization of education with a completely new principle - the organization of educational work around the goals of students, the idea of separating student behavior as a starting point of education. Such an approach, in our opinion, leads to the elimination of conflicts in the educational process, the strengthening of mutual goodwill (sincerity) between teacher and student, increasing the effectiveness of interaction. 
CURRENT RESEARCH JOURNAL OF PEDAGOGICS 2(9): 159-171,

September 2021 DOI: https://doi.org/10.37547/pedagogics-crjp-02-09-34

ISSN 2767-3278

(C)2021 Master Journals

\section{Crossref do) 8 Google}

Accepted 25 $5^{\text {th }}$ September, 2021 \& Published $30^{\text {th }}$ September, 2021

Purposeful creative mastery is a promising activity that strives for the future. Acquisition of knowledge according to their behavior, aspirations, activities develops in children the experience of creative activity. A goal is a preconceived, planned outcome that requires conscious activity from a person. The achieved goal becomes the result, the next - the achieved result becomes a means to achieve the newly set goals.

Creative mastery performs a number of tasks in the student's activity: to anticipate new problems that arise in life, in production; to think of new ways of solving problems, to be able to find them, to be able to transfer the learned knowledge to new conditions; creative use of knowledge, skills, experience of creative activity. A student who possesses such personal qualities will be able to participate in social life without difficulty. Preparing students for life is a functional feature of creative mastery.

Creative mastery also requires educational tools appropriate to their nature. The effective interaction of teaching and learning takes place not spontaneously, but through a system of didactic tools. Without taking this situation into account, it is impossible to understand the progressive movement in the development of the educational process. There are two types of training tools: material means, materialized means. In the educational process, the teacher puts material and materialized means between himself and the students. The material and tangible means placed between the teacher and the students in the educational process are the means for the teacher and the source of education for the children. The tools for the reader are in itself. The methods of work, mental activity, life experience, acquired knowledge, traditions and activities that are historically established in the national culture, used in problem solving and learning tasks, serve as a tool for students.
In technology education, there are three different levels of mastery of teaching materials in the technology of designing creative activities of students related to national crafts, and three different outcomes corresponding to these three different levels.

I degree. At this level, the learning outcome should be appropriate to the overall structure of the learning material and the ways in which it can be narrated. In other words, the image of the learning material must be formed in the mind of the reader.

Level II. Defining and expanding the general structure of the study material and methods of its presentation. At this level, the knowledge in the mind of the reader becomes clearer, more active.

III degree. Mastering the learning material at the level of understanding. At the level of understanding, the acquired knowledge becomes a dynamic system in which the student takes his or her place. Thus, as the learner rises from a lower level of mastery to a higher level, the knowledge in his mind takes on the status of a moving concept and becomes the personal property of the learner [15].

Remembering and creativity in mastering learning materials are two sides of the same process - the process of achieving a pre-recorded outcome. Learning activities that begin with recollection should end with recollection, which begins with creativity. Creative activity brings the reader closer to the object of study through recollection. The more the reader encounters the object of mastery, the more he realizes new features for himself. This is a cumulative phenomenon in the learning process, the repeated encounter with the object of assimilation leads to the enrichment of the mind with new perceptions about that object. It can be seen that the development of creative abilities is analyzed in the context of the concept of creative 
CURRENT RESEARCH JOURNAL OF PEDAGOGICS 2(9): 159-171,

September 2021 DOI: https://doi.org/10.37547/pedagogics-crjp-02-09-34

ISSN 2767-3278

(C)2021 Master Journals

Crossref do: 81 Google

Accepted 25 $5^{\text {th }}$ September, 2021 \& Published 30th September, 2021

mastery. Creativity is the core of the organizational system, which is above itself creative mastery.

Giving a general description of the content, purpose, means, results of the activity, highlighting the characteristics of each of the learning activities and cognitive activities of students. By comparing learning activities and cognitive activities, he substantiated a number of dimensions of the creative organization of technology education. Creative organization of education is:

- Changing the status of the student in education, making him a subject of the educational process;

- Conducting education beyond the scope of normative education;

- Orientation of students' activities to the complex of knowledge, skills, experience of creative activity, relationships;

- Organization of education with a specific purpose, means, results, motives;

- Thought-oriented education;

- To encourage students to master the future (to become an educated citizen in the future) [25].

The technology of designing creative activities of students in the field of national crafts in technology education allows:

- Forms the need for knowledge in students;

- activates the cognitive activity of students;

- Increases students' interest in studying science;

- Increases the desire to learn to work with information;

- introduces the world to modern methods of scientific knowledge;

- Increases the level of individuality of the student in education;

- develops creative abilities of students;

- $\quad$ ensures the diversity of material content;

- expands the range of teaching materials used in technology education;

- expands students' self-control, ie the factors of the assessment process, etc. [24].

In technology education, the design of students 'creative activity is projected primarily in the mind. In this process, all the work that the student can do must be taken into account. Any lesson is organized according to a certain educational model. Exploring the possibilities of designing educational models and selecting the most appropriate ones will increase the effectiveness of education.

Well-structured projects play a key role in creative education. Explanatory-visual, problembased, task-based, differential, programmed, algorithmic, etc. of education. types, and it is advisable to organize them on the basis of design features.

In accordance with the above concept, we distinguish three main directions in the study of the problem of technology design of creative activities of students in the national craft in technology education: first line - subjects of education - the work of teachers and students on the implementation of "project education". The effectiveness of education cannot be ensured without shaping the perceptions of teachers and students about project-based learning. The second direction - the content of education, in this case the science of technology is related to the content of the subject with the process of pedagogical development and design. In this direction, we note the study of the principles, tools, methods of organization, management, control of education through design.

The third line - " Designing students' creative 
CURRENT RESEARCH JOURNAL OF PEDAGOGICS 2(9): 159-171,

September 2021 DOI: https://doi.org/10.37547/pedagogics-crjp-02-09-34

ISSN 2767-3278

(C)2021 Master Journals

\section{Crossref do) 8 Google}

Accepted 25 $5^{\text {th }}$ September, 2021 \& Published $30^{\text {th }}$ September, 2021

activities in technology education is the most effective means of education ". Based on this idea, we understand the design of creative activities of students to study the conditions for improving the quality and efficiency of educational work. The organization and conduct of research in the mentioned areas will undoubtedly lead to a statement of the theoretical foundations of the design of technology science teaching.

In short, the problem of technology in the design of creative activities of students in the field of national crafts in technology education includes the organization of creative study of the content of education, creative mastery, education of creative abilities.

\section{REFERENCES}

1. Mirziyoev Sh.M. Together we will build a free and prosperous, democratic state of Uzbekistan. T .: - "Uzbekistan”, 2017-546.

2. Mirziyoev Sh.M. Critical analysis, strict discipline - discipline and personal responsibility - should be the daily rule of every leader's work. Report of the enlarged meeting of the Cabinet of Ministers on the main results of socio-economic development of the country in 2016 and the most important priorities of the economic program for 2017. January 14, 2017. Tashkent: “Uzbekistan”, 2017. -104 p.

3. Mirziyoev Sh.M. Together we will build a free and prosperous, democraticstate of Uzbekistan. Speech at the joint session of the chambers of the Oliy Majlis dedicated to the inauguration ceremony of the President of the Republic of Uzbekistan / Sh.M. Mirziyoev. - Tashkent: "Uzbekistan”, 2016. $56 \mathrm{p}$.

4. Baykov F.Ya. Learning and creativity. -L .:
Leninizdat, 1979. -149 p.

5. 5.Vysotskaya S.I. Didactic aspects of the problem of pedagogical design. Novye issledovaniya $\mathrm{V}$ pedagogicheskix naukax, №1 (43), -M .: Pedagogika, 1984. -s. 26-29.

6. 6.Isyanov R.G. Cluster approach to the formation of modular competencies of the predecessors of higher educational institutions. - Tashkent: TGPU, 2014. - 69 p.

7. 7.Muraveva G.E. Proektirovanie tehnologiy obucheniya: Ucheb.posobie dlya studentov i prepodavateley ped. vuzov, slushateley i prepodavateley kursov povыsheniya kvalifikatsii uchiteley /G.E. Muraveva. Ivanovo, 2001. - $123 \mathrm{p}$.

8. 8.Muslimov N.A. Theoretical and methodological bases of professional formation of teachers of vocational education .: Author's ref. dis. ... ped. fan.dokt. - T .: 2007. - 45b.

9. Ismatullayeva, N. R. (2021). On the Introduction of E-Learning Portfolio in the Educational Process. Current Research Journal of Pedagogics (2767-3278), 2(09), 35-37.

10. 10.Shomirzaev M.X. Genesis of formation and development technology of Uzbek national handicrafts. Educationalmethodical manual. -T .: New edition, 2016. $-88 \mathrm{p}$.

11. MX Shomirzayev. (2019) Innovative processes in Uzbek national handicrafts. T.:"New edition".

12. Shomirzaev M.X. Theory and practice of interdisciplinary improvement of spectralvariable components of national crafts in school technology education. Monograph. T .: Tafakkur, 2020. - 164 p.

13. Shomirzaev M.X. Factors of interdisciplinary formation of students' 
CURRENT RESEARCH JOURNAL OF PEDAGOGICS 2(9): 159-171,

September 2021 DOI: https://doi.org/10.37547/pedagogics-crjp-02-09-34

ISSN 2767-3278

(C)2021 Master Journals

\section{Crossref do) 8 Google}

Accepted 25 $5^{\text {th }}$ September, 2021 \& Published 30 ${ }^{\text {th }}$ September, 2021

interest in folk crafts // School and life. - T., 2019. - Issue 6. - B. 23-24.

14. Shomirzaev M.X. Problems of using educational technologies // Modern education. - T., 2019. - 9 (82) -son. - B. 25-3.

15. Shomirzaev M.X. Genesis of formation and development technology of Uzbek embroidery // Teacher and continuous education. -Nukus, 2019. - 5-son. - B. 73-82.

16. Shomirzaev M.X. The use of educational technologies in the formation of students' interest in the professions of national crafts // Karakalpak State University Bulletin. Nukus, 2019. - 4 (45) -son. - B. 98-102.

17. Shomirzaev M.X. Local aspects in traditional embroidery // Sources of knowledge. Urgench, 2019. - Issue 8. - B.140-144.

18. Shomirzaev M.X. Vocational education: national embroidery // Pedagogy. - T. 2019. - 3-son. - B.122-129.

19. Shomirzaev M.X. The art of embroidery and its peculiarities // Bulletin of Karakalpak State University. - Nukus, 2020. - 4 (46) son. - B.91-95.

20. Shomirzaev M.X. Improving the orientation of students to the professions of folk crafts in technology education // Science and society (Science is also society). - Nukus, 2020. - 2nd issue. - B. 98-100.

21. Shomirzaev M.X. Inter-ethnic peculiarities of embroidery. // Sources of knowledge. Urgench, 2020. - Issue 4. -B. 189-192.

22. The use of modern educational methods in teaching school students to folk crafts // Teacher and continuous education. - Nukus, 2020. - 2nd issue. - B. 42-46.

23. Shomirzaev M.X. The use of modern teaching methods in teaching school students folk crafts. // The teacher is also constantly informed. - Nukus, 2020. - 3rd issue. - B. 42-46.

24. Shomirzayev, M.Kh. (2019). The ethical characterics of traditional embroidery of Fergana valley people. European Journal of Research and Reflection in Educational Sciences, 7 (12). - P. 55-59.

25. Shomirzayev, M.Kh. (2019). Ethnic peculiarities of artistic embroidery of the peoples of the Ferghana valley. European Journal of Research and Reflection in Educational Sciences. -7 (12). -P. 966-969.

26. Shomirzayev, M. K. (2020). National handicrafts of Uzbekistan and its socialeconomic significance. European Journal of Research and Reflection in Educational Sciences, 8(8), 129-138.

27. Shomirzayev, M. K. (2021). Practical lessons in technology: Characteristics of organization and conduct. ASIAN JOURNAL OF MULTIDIMENSIONAL RESEARCH, 10(4), 991-1001.

28. Shomirzayev, M. K. (2021). Combined In Technology Courses Use of Technologies. The American Journal of Social Science and Education Innovations, 3(05), 389-396.

29. Shomirzayev, M. K., \& Yuldashov, K. K. (2021). THE EDUCATIONAL IMPORTANCE OF TEACHING KNOWLEDGE TO SECONDARY SCHOOL STUDENTS. CURRENT RESEARCH JOURNAL OF PEDAGOGICS (2767-3278), 2(08), 132-142.

30. Shomirzayev, M. K. (2021). Developing educational technologiesin school technology education. ASIAN JOURNAL OF MULTIDIMENSIONAL RESEARCH, 10(5), 73-79 